\title{
Fitness callanetics in physical education of girl students
}

\author{
Kolomiytseva O.E. ${ }^{1}$, Anatskyi R.V. ${ }^{2}$ \\ ${ }^{1}$ Yaroslav Mudryi National Law University \\ ${ }^{2}$ The National Academy of the National Guard of Ukraine
}

\begin{abstract}
Purpose:

Material: $\quad$ in the research 1st year girl students of age 16-17 years $(n=35)$ participated. The girls were trained in Callanetics sport circle twice a week in free time. Every training lasted 60 minutes. The program was designed for 72 hours and contained: theoretical part, practical part, control part, tasks for independent work and eating recommendations.

Results: $\quad$ motives for girl students' practicing callanetics were found. We registered positive changes in anthropometric indicators, power abilities and flexibility. After two months' training body mass of girl students reduced. We showed need in changing physical culture trainings' forms and methods in universities. It is offered to actively use static-dynamic exercises.

Conclusions: when fulfilling callanetics exercises one should strictly follow a number of methodic techniques, which will increase trainings' effectiveness and make them health related.

Keywords: girl students, callanetics, motivation, mass, body, power abilities, flexibility.
\end{abstract}

\section{Introduction}

Starting adult life by first year students is an important step, requiring mobilization of young organism's all systems and organs. First year of study in higher educational establishment is usually connected with student's adaptation to new life conditions and life positions' formation in student's personality. In this period, physical culture teacher plays especial role of pedagogue, orator and animator in one person. It permits to stimulate student for formation valuable attitude to personal motor functioning, to cultivate demand in regular physical culture practicing.

Seeking of new of physical education innovative technologies, which would be of health related character and meet youth's requirements are important problem for teachers [10, 11, 14, 18]. Physical culture classes shall motivate students for systemic physical exercises' practicing. A number of scientific works is devoted to new approaches to students' physical education. The authors note that at physical culture classes more attention shall be paid to cultivation students' personal components of healthy life style $[16,17,25]$. Besides, scientists found that both: traditional physical culture lessons and specialized ones approximately equally influence on formation of healthy life style personal components in students.

To fight successfully with students low physical condition and poor health authors recommend to use HOT IRON exercises, which positively influence on girls and boys' power and endurance [25]. Besides, positive influence of health related trainings, based on aqua-aerobic, on students' physical workability is noted [28]. Chinese health related gymnastic Wushu, practiced barefoot and under musical accompaniment, improves students' self feeling and increases their psychic and physical workability [23]. That is why it would be purposeful to use fitness Yoga programs for girl students [30].

In recreational and health related spheres of students' (c) Kolomiytseva O.E., Anatskyi R.V., 2017 doi:10.15561/20755279.2017.0203 physical education special place is taken by callanetics and Pilates. Pilates positive influence on cardio-respiratory indicators of healthy students is mentioned in many works $[21,24]$. The authors note that after 10 weeks' course indicators of heart beats rate improved (135.4-124.2 bpm) as well as breathing coefficient (1.1-0.9). Pilates practicing weakens stress, anxiety, fatigue and improves students' self-feeling and motivation [15, 21, 26, 27].

Theoretical principles of motivation's formation for callanetics practicing by students are regarded in other works $[5,8]$. Their authors note that insignificant intensity and easiness of callanetics exercises permit to recommend them for application at physical education trainings of students with posture disorders $[4,10,11]$.

Analysis of literature sources showed that fitness directions have become an important reserve of physical culture health related-recreational system for students.

In connection with the above mentioned it seems to be relevant to work out author program "Callanetics" and implement it in girl students’ physical education.

Hypothesis: it is assumed that for successful strengthening of students' physical condition, physical fitness and health it is necessary to change physical culture forms and methods in universities. It is offered to actively apply static-dynamic exercises - CALLANETICS. This system implies fulfillment of exercises without objects, with dumbbells and balls. It facilitates development of girl students' flexibility, strength and power endurance.

The purpose of the work is to study callanetics as modern direction in girl students' physical education.

\section{Material and methods}

Participants: in the research $1^{\text {st }}$ year girl students of age 16-17 years $(n=35)$ participated. By results of medical examination all girl students were related to main health group (having no health problems) and preparatory health group (with insignificant health problems).

Organization of the research: in the research $1^{\text {st }}$ year girl students of age 16-17 years $(n=35)$ participated. 
Before the researches we analyzed students' medical records for recent five years. Than we questioned first year students to find their interests and motives for systemic motor functioning practicing.

Main research was fulfilled in October-November 2016-2017 academic year. Girl students attended Callanetics sport circle twice a week in free time. Every training took 60 minutes and consisted of warming up, main part and final part (with breathing and relaxation exercises).

As the base of callanetics program we used psychological-pedagogic pre-conditions of formation of motivation for physical culture practicing [7]. The program includes targeted, functional and resulting blocks.

Targeted block is a spectrum of targets and tasks to be realized in formation of motivation for callanetics practicing. The main tasks of this block are:

1. Determination of girl students' health by medical examination; в

2. Finding of motives and reasons influencing on practicing different kinds of physical activity;

3. Stage-by-stage control of power abilities, flexibility and functional indicators' level.

Functional block components:

1. Training: training of exercises and development of physical qualities. It implies: formation of knowledge about callanetics as a mean of student's physical education and personal physical culture as well as working out of program-methodic complex for callanetics training.

2. Cognitive - includes formation of students' knowledge about callanetic exercises' application in physical education, independent trainings, optimization and increase of own organism's functional potentials in learning and working life activity.

3. Axiological - means formation students' ideas about physical culture and callanetics as means of health protection and improvement, rational eating and avoiding harmful habits. Such understanding shall become an integral part of healthy life style.

4. Motivational component includes formation of firm interest and desire to practice callanetics as means of physical form, good self feeling and mood sustaining.
Resulting block implies receiving data of all blocks. Further analysis of these data will permit to conclude about effectiveness of the worked out and implemented in practice complex "Callanetics".

In our research we registered girl students' weightheight indicators, results of strength and flexibility testing. Strength was tested with the following exercises: 1) "incomplete torso rising" from lying on back position, arms are stretched along torso, hands touch starting mark. Girl student raises head and shoulders with lower edge of shoulder blades being immobile. The quantity of risings is registered. 2) "Lying on forearms" Initial position (I.p.) is lying on forearms, with feet parted on width of hip joints. Girl student takes position of "plank" with the back of the head, shoulders, shoulder blades and buttocks being on one line. No arching in lumbar spine is admitted. The time of keeping such position is registered. 3) "Pressing ups in lying position”, quantity of times. For backbone flexibility traditional test was used: 'forward bending. I.p. was sitting position with legs parted.

Statistical analysis: was fulfilled with the help of Ecxel program. We calculated mean arithmetic (Xav); error of mean arithmetic (m), variation coefficient (V). Differences between mean values were assessed with Student's t-test.

\section{Results}

On initial stage of our research we fulfilled analysis of girl students' health fir recent five years. We analyzed medical records of 1349 first year girl students. Medical personnel of the university traditionally distribute students into health groups: main, preparatory and special. Separately there exists group of therapeutic physical culture for students with in-born health problems.

As we can see in fig., the quantity of healthy students is reducing. For example for recent five academic years percentage of main group students decreased from $88.62 \%$ (at the beginning of $2011-2012$ ac. yr.) to $68.7 \%$ (in 2015-2016 ac. yr.). Percentage of students with light health problems (preparatory health group) changed in heterochronic way. At the same time percentage of special health group students increased more than two times (from $6.4 \%$ to $15.1 \%$ ).

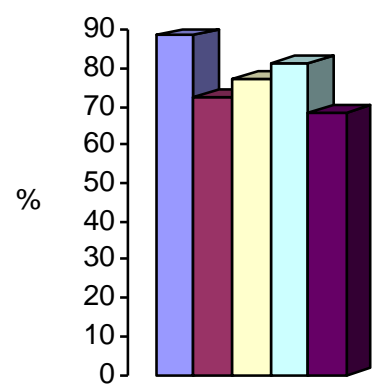

A

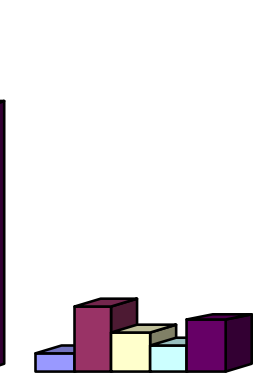

B

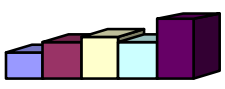

C
口 2011-2012 2012-2013

ㅁ2013-2014 ㅁ2014-2015

口 2015-2016

Fig.1. Students' distribution into health groups for recent five academic years 2011-2016

A - main group; B - preparatory group; C - special group; D - group of therapeutic physical culture (TPC); HG - health groups. 
At the beginning of 2011-2012 ac. yr. there were registered single cases $(0.6 \%)$, when, by results of medical examination, students, in connection with heavy diseases, were oriented on therapeutic physical culture. During period of study the quantity of such students increased several times (up to $3.2 \%$ ). Especially troublesome is the fact that, by different reasons, students often disguise their actual health state.

First year of study requires formation of contact between teacher and student, cultivation of healthy life style skills in students, application of innovative technologies in physical education sphere.

Then we carried out questioning for understanding motives for active practicing of physical culture (callanetics in particular). As the main motives, students called: wish to have handsome constitution", "receive positive emotions through movements", "to be healthy", "it is in fashion to watch oneself".

On the base of questioning results and medical records' analysis we worked out program-methodic complex "Calanetics" for first year students. The program is designed for 72 hours and includes theoretical, practical and control parts as well as tasks for independent work and eating recommendations.

Callanetics is slow, quiet gymnastic with static loads. Such trainings facilitate strengthening of muscles and reduction of body mass and volume. The trainings are of traditional structure: preparatory part, main part and finalizing part. Duration of training is 60 minutes.

When training, it is necessary to observe some methodic techniques:

1. Callanetics is a gymnastic of uncomfortable positions and requires constant concentration of attention in every exercise;

2. Loads' intensity and duration shall be increased gradually. Load increment shall be $3-5 \%$ every week. At initial stage, minimal time for every posture shall be 30 sec. and be increased gradually up to $100 \mathrm{sec}$.;

3. Static-dynamic character of movements implies fulfillment of exercises in static regime of muscles' work. If movement is necessary, it shall be smooth. Sharp movements are not recommended. Traveling shall not be more than 1-2 cm;

4. Main part shall ensure variability of exercises. Traditional complex of callanetics system consists of 30 exercises of different orientation: exercises for muscles' warming up (6); exercises for abdomen muscles' strengthening (4), for legs (6), for thighs and buttocks (5); stretching exercises (6); "Belly dance" exercises (3). Recent years, callanetics specialists have started to use exercises from Yoga and Pilates. It significantly expanded such trainings' influence on human organism. If training consists of traditional exercises, their quantity can be 7 - 12. If instructor uses exercises from other systems, the quantity of exercises can reach 20 and more.

5 . Muscular groups of all body parts shall be involved in every training;

6. Shallow, calm breathing plays important part in callanetics. In every exercise it is necessary to breathe rhythmically, but without any pauses. It is up to student to choose correlation of inhales and exhales: $1: 1,1: 2$ or $1: 3$. Power element of exercise shall be accompanied by exhale; relaxation - by inhale. At initial stage of training it is recommended to use correlation: 1 inhale to 1 exhale. With experience and fulfilling exercises for abdomen muscles it is recommended to use correlations $1: 2$ and 1:3.

7. Every training shall include special time for exercises for diaphragm breathing and for flat foot prophylaxis. As relaxation between exercises the following exercises for backbone relaxation are practiced: grouped rolls with different amplitude, self-massage and massage.

8. Practically all exercises, except stretching, require taking callanetics classic stance - the so-called “oppositional stretching” [2]. It shall be mastered in the first training. In fulfillment of motor task it is necessary to control correctness of this stance during all exercise.

9. Trainings shall be systematic. Only regular trainings can give maximal effect. That is why in vacation time callanetics trainings shall be practiced independently, at home.

Results of health related motor functioning practicing are realization of student's demands and motives, which made him/her to train: improvement of self-feeling, reduction of body volume, absence of pains and so on. To ensure objectiveness of organism changes' assessments we introduced tests in "Callanetics" complex. Assessment of physical condition is possible with control over anthropometric indicators: body length and weight. The Quetelet index is calculated by these two indicators. By results of Quetelet index body composition is assessed [9]; circumference of relaxed arm, circumference of waist, buttocks, thigh and shin. Development of physical qualities is assessed with tests for joints mobility: forward torso bending from sitting position (standing on bench); arms positioning behind back. Muscular strength is determined with the following tests: incomplete torso rising; pressing ups in lying position; keeping of "plank" posture on forearms or arms. Functional potentials of respiratory system are assessed with the following tests: vital capacity of lungs (VCL); Stanger and Genchi tests [6]. In the course of trainings students often change initial position from lying to sitting. Functional efficiency of reflex mechanisms of haemo-dynamic regulation and excitability of sympathetic innervations centers can be effectively estimated with the help of orthostatic test.

In table 1 weight-height indicators of girl students are presented as well as results of strength and flexibility testing.

Analysis of initial data shows certain body mass excess in 17 years age girl students. For the analysis we used Quetelet index for people of different age [9]. After two months' trainings we observed increase of girls' mean body length value and reduction of body mass in average by $1.4 \mathrm{~kg}$. It facilitated reducing of body mass index.

Girl students power abilities changed positively. In exercises "Incomplete torso rising" results increased by $13.2 \%$. It means improvement of abdomen muscles' power endurance (power center). Indicators of exercise 
Table 1. Weight-height indicators of girl students and results of strength and flexibility testing

\begin{tabular}{|c|c|c|c|c|c|c|c|c|c|}
\hline \multirow[t]{2}{*}{ Indicators } & Xav & m & V & & m & V & & m & V \\
\hline & \multicolumn{3}{|c|}{$1^{\text {st }}$ training } & \multicolumn{3}{|c|}{ After 8 trainings } & \multicolumn{3}{|c|}{ After 16 trainings } \\
\hline \multicolumn{10}{|l|}{ Anthropometrical indicators } \\
\hline Body length, $\mathrm{cm}$ & 166,7 & 4,69 & 2,81 & 166,76 & 4,64 & 2,78 & 167,0 & 4,60 & 2,75 \\
\hline Body mass, kg & 63,73 & 6,44 & 10,1 & 63,13 & 5,92 & 9,37 & 62,33 & 4,87 & 8,42 \\
\hline Quetelet index & 23,17 & & & 22,95 & & & 22,34 & & \\
\hline \multicolumn{10}{|l|}{ Power abilities } \\
\hline $\begin{array}{l}\text { Incomplete torso rising, } \\
\text { times }\end{array}$ & 24,2 & 4,88 & 20,16 & 25,26 & 4,26 & 16,86 & 27,0 & 3,87 & 14,33 \\
\hline Lying on forearms, sec. & 22,13 & 5,52 & 24,9 & 23,67 & 4,23 & 17,87 & 26,66 & 3,24 & 12,15 \\
\hline $\begin{array}{l}\text { Pressing ups in lying } \\
\text { position, times }\end{array}$ & 8,8 & 1,37 & 15,56 & 9,53 & 1,06 & 11,12 & 10,33 & 0,81 & 7,84 \\
\hline \multicolumn{10}{|l|}{ Flexibility } \\
\hline $\begin{array}{l}\text { Forward torso rising from } \\
\text { sitting position, } \mathrm{cm}\end{array}$ & 11,26 & 2,52 & 22,2 & 11,93 & 1,90 & 15,92 & 12,33 & 1,54 & 12,52 \\
\hline
\end{tabular}

Note: mean arithmetic (Xav); error of mean arithmetic $(\mathrm{m})$; variation coefficient $(\mathrm{V})$

"Lying on forearms" increased by $20 \%$. Besides, backbone flexibility increased that is witnessed by results of test "forward torso bending from sitting position".

\section{Discussion}

Students more and more often wish to practice modern and creative kinds of sports, forming motivation for systematic trainings.

The breadth of the problem of students health worsening is proved also by results of our studies. In opinion of a number of scientists in post-Soviet HEEs more than $50 \%$ of students have health problems [29, 30]. The authors say that such situation results from crisis state of physical education system $[5,14,20]$. The data, received by us, prove correctness of such opinions. It is connected with the fact that one academic lesson a week is quite insufficient for sustaining optimal physical form of a student.

We have worked out authors program "Callanetics" and implemented it into practice of girl students' physical education. This kind of motor activity is popular in fitness field and can be one of variants of students' motivating for systemic physical culture practicing $[3,5]$. Results of our researches prove the opinion about usefulness of modern approaches to students' physical education application (principle "motivation instead of compulsion") [20, 32].

Our results prove the data about possible application of different fitness kinds in students' teaching [28-31]. There are data about effective callanetics' application for osteoporosis prophylaxis in second maturity women (44-55 years) [1]. Exercises' fulfillment smoothly without sharp jerks, in static and static-dynamic modes - is characteristic peculiarity of callanetics exercises. These exercises are directed at micro contraction of surface and deep muscles. It results in quick reduction of deep fat layers [8]. Our researches prove this fact. The reason of body length change is oppositional stretching of backbone, preceding and finalizing nearly every exercise. Besides, our data and results of other research [2] witness about positive influence of callanetic exercises on students' physical condition (reduction of body mass).

\section{Conclusions:}

Analysis of medical records showed progressing decrease of healthy girl students' quantity. Alongside with it, with every year more and more girl students become member of special health groups and so, they are recommended to practice therapeutic physical culture.

Questioning results permitted to find main motives, on which girl students based, when choosing callanetics training: "desire to have handsome body constitution", "receive positive emotions through movements", "to be healthy", "it is in fashion to watch oneself".

Fulfillment of callanetics exercises requires observation of a number of methodic techniques, which make trainings effective and health related. Distinctive feature of such exercises is correct breathing and keeping working posture.

Two months' cycle of callanetics practicing permitted to register insignificant increase of body length mean indicator and reduction of body mass. These trainings also rendered positive influence on strength and backbone flexibility of girl students.

\section{Conflict of interests}

The author declares that there is no conflict of interests. 


\section{References}

1. Bradulova EV, Gradusov VA. Vliianie zaniatij statikodinamicheskoj gimnastikoj na uroven' fizicheskogo sostoianiia zhenshchin zrelogo vozrasta (45-55 let) [Influence of static-dynamic gymnastic trainingson mature women's physical condition (45-55 years)]. Slobozhans'kij naukovosportivnij visnik, 2008;4:57 - 60. (in Russian)

2. Bradulova EIu. Povyshenie effektivnosti profilaktiki osteoporoza sredi zhenshchin vtorogo zrelogo vozrasta (4555 let): primenenie kompleksa LFK «KALLANETIKS» [Increase of osteoporosis prophylaxis effectiveness among second maturity women (45-55 years): application TPC complex "CALLANETICS"]. Slobozhans'kij naukovosportivnij visnik, 2009;2:105 - 109. (in Russian)

3. Gerasimenko S. Obgruntuvannia metodiki vikoristannia kalanetiki u fizichnomu vikhovanni studentiv VNZ [Substantiation of callanetics' application methodic for HEE students physical education]. Nova pedagogichna dumka, 2014;1:105 - 107. (in Ukrainian)

4. Dubchuk OV. Ocinka vplivu eksperimental'noi programi fizichnogo vikhovannia dlia grup fizichnoi reabilitacii iz zastosuvanniam kallanetiki na pokazniki rentgenologichnogo ta funkcional'nogo doslidzhennia oporno-rukhovogo aparatu studentok pri skoliozi II-III stupeniv [Influence of physical education experimental program with callanetics elements in physical rehabilitation groups on indicators of X-ray and functional testing of muscular-skeletal apparatus in girl students with scoliosis of 1-3 ${ }^{\text {rd }}$ degree]. Nova pedagogichna dumka, 2013;4 (76):100-104. (in Ukrainian)

5. Kolomijceva OE, Dejneko AKh, Mirgorod DA. Kallanetika kak sredstvo formirovaniia motivacii k zaniatiiam fizicheskim vospitaniem studentok iuridicheskogo vuza [Callanetics as a mean of motivation formation for physical education lessons among Law HEE girl students]. Nauka i osvita, 2015;4:86 - 89. (in Russian)

6. Krucevich TIu, Vorobjov MI, Bezverkhnia GV. Kontrol'u fizichnomu vikhovanni ditej, pidlitkiv $i$ molodi [Control in physical education of children, adolescents and youth]. Kiev: Olympic Literature; 2011. (in Russian)

7. Kulikova TM. Formirovanie motivacii k zaniatiiam fizicheskoj kul'turoj uchashchikhsia starshikh klassov s oporoj na tradicii karate [Formation of senior pupils' motivation for physical culture lessons, basing on Karate traditions]. Fizicheskaia kul'tura: vospitanie, obrazovanie, trenirovka, 2014;6:9-11. (in Russian)

8. Kulish NM, Gorodis'kij SI. Vpliv zasobiv kalanetiki na pokazniki fizichnogo rozvitku ta rukhovikh iakostej $\mathrm{u}$ studentok [Influence of callanetics means on physical condition and motor skills' indicators of girl students]. In: Luk'ianchenka $\mathrm{M}$ et at al. (red). Realizaciia zdorovogo sposobu zhittia - suchasni pidkhodi [Realization of healthy life style - modern approaches], Drobobych: CIRCLE; 2007. P. 60-63. (in Ukrainian)

9. Sergiienko LP. Sportivna metrologiia [Sports metrology]. Kiev: KNT; 2010. (in Russian)

10.Arziutov G, Iermakov S, Bartik P, Nosko M, Cynarski WJ. The use of didactic laws in the teaching of the physical elements involved in judo techniques. Ido Movement for Culture, 2016;16(4):21-30. doi:10.14589/ido.16.4.4

11. Bliznevsky AA, Kudryavtsev MD, Iermakov SS, Jagiello W. Formation of active-effective attitude of 12-13 years' judo athletes to sports functioning in competition period. Archives of Budo. 2016;12:101-15.

12. Chen CH, Chen TC, Jan MH, Lin JJ. Acute Effects of Static Active or Dynamic Active Stretching on Eccentric-Exercise-
Induced Hamstring Muscle Damage. International Journal of Sports Physiology and Performance. 2015;10(3):346-52.

13.Diaz-Soler MA, Vaquero-Cristobal R, Espejo-Antunez L, Lopez-Minarro PA. The effect of a warm-up protocol on the sit-and-reach test score in adolescent students. Nutricion Hospitalaria. 2015;31(6):2618-23.

14.Futornyi SM. Problem of shortage of motor activity students. Physical education of students, 2013; 17(3): 75-79. doi:10.6084/m9.figshare.663631

15.Gong W. The effect of bridge exercise accompanied by the abdominal drawing-in maneuver on an unstable support surface on the lumbar stability of normal adults. Journal of Physical Therapy Science. 2015;27(1):47-50.

16.Iermakov SS, Arziutov GN, Jagiello W. Quick training of students to judo techniques. Archives of Budo. 2016;12:1524.

17.Iermakov SS, Podrigalo LV, Jagiello W. Hand-grip strength as an indicator for predicting the success in martial arts athletes. Archives of Budo. 2016;12:179-86.

18.Ilnitskaya AS, Kozina ZhL, Lakhno E G, Ilnitskaya LV, Cieślicka Mirosława, Stankiewicz Błażej, Pilewska Wiesława. Students' attitude to the possibility of applying modern information and communication technologies in the educational process in physical education. Physical education of students, 2014; 18(2): 18-24. doi:10.6084/ m9.figshare. 906369

19.June Kloubec, Aaron L Banks. Pilates and Physical Education: A Natural Fit. Journal of Physical Education, Recreation and Dance, 2004;75:34-37

20.Kondakov VL, Kopeikina EN, Balysheva NV, Usatov AN, Skrug DA. Causes of declining interest of students to employment physical education and sports. Physical education of students, 2015; 19(1): 17-21. doi:10.15561/20755279.2015.0103

21.Konul Memmedova. Impact of Pilates on Anxiety Attention, Motivation, Cognitive function and Achievement of Students: Structural Modeling. 5th World Conference on Learning, Teaching and Educational Leadership, WCLTA 2014. Procedia - Social and Behavioral Sciences, 2015;186:13: 544-548.

22.Kudryavtsev MD, Kramida IE, Iermakov SS, Osipov AYu. Development dynamic of healthy life style personality component in relatively healthy students. Physical education of students, 2016; 20(6): 26-33. doi:10.15561/20755279.2016.0603

23.Maksimuk OV, Vrublevskiy EP, Lin Wang. Students' motivation to study Chinese recreational gymnastics classes wushu.Physical education of students, 2014; 18(3): 40-43. doi:10.6084/m9.figshare.974479

24.Maria Tinoco-Fernández, Miguel Jiménez-Martín M, Angeles Sánchez-Caravaca, Antonio M Fernández-Pérez, Jesús Ramírez-Rodrigo, Carmen Villaverde-Gutiérrez. The Pilates method and cardiorespiratory adaptation to training. Research in Sports Medicine, 2016;24:266-271.

25.Osipov AYu, Kudryavtsev MD, Kramida IE, Iermakov SS, Kuzmin VA, Sidorov LK. Modern methodic of power cardio training in students' physical education. Physical education of students, 2016; 20(6): 34-39. doi:10.15561/20755279.2016.0604

26.Park MH, Yu JH, Hong JH, Kim JS, Jung SW, Lee DY. Effect of core muscle thickness and static or dynamic balance on prone bridge exercise with sling by shoulder joint angle in healthy adults. Journal of Physical Therapy Science. 2016;28(3):945-50.

27.Park YH, Park YS, Lee YT, Shin HS, Oh MK, Hong J, et al. 
The effect of a core exercise program on Cobb angle and back muscle activity in male students with functional scoliosis: a prospective, randomized, parallel-group, comparative study. Journal of International Medical Research. 2016;44(3):72834.

28.Petrenko NV, Loza TA. Model of recreational and training sessions based on the use of funds aqua professionally applied in the preparation of students of economics. Physical education of students, 2014; 18(4): 32-36. doi:10.6084/ m9.figshare.974481

29.Skidan AA, Sevdalev SV, Vrublewskiy EP. Content of health related shaping training methodic for girls in the process of physical education. Physical education of students, 2015; 19(6): 56-62. doi:10.15561/20755279.2015.0608
30.Skurikhina NV, Kudryavtsev MD, Kuzmin VA, Iermakov S S. Fitness yoga as modern technology of special health groups' girl students' psycho-physical condition and psychosocial health strengthening. Physical education of students, 2016; 20(2): 24-31. doi:10.15561/20755279.2016.0204

31.Struhar I, Dovrtelova L, Reguli Z. Influence of two years study in Special Education of Security Sections on the body posture. Archives of Budo. 2015;11:359-64.

32.Zakaria AA, Kiningham RB, Sen A. Effects of Static and Dynamic Stretching on Injury Prevention in High School Soccer Athletes: A Randomized Trial. Journal of Sport Rehabilitation. 2015;24(3):229-35.

\section{Information about the authors:}

Kolomiytseva O.E.; http://orcid.org/0000-0003-4463-5027; olga86-76@mail.ru; Yaroslav Mudryi National Law University; Pushkinskaya street, 77 Kharkov, 61024, Ukraine.

Anatskyi R.V.; http://orcid.org/0000-0002-5662-9903; ruslan. anackii@mail.ru; The National Academy of the National Guard of Ukraine; Povstannya Square 3, Kharkov, 61001, Ukraine.

Cite this article as: Kolomiytseva OE, Anatskyi RV. Fitness callanetics in physical education of girl students. Physical education of students, 2017;2:66-71. doi:10.15561/20755279.2017.0203

The electronic version of this article is the complete one and can be found online at: http://www.sportedu.org.ua/index.php/PES/issue/archive

This is an Open Access article distributed under the terms of the Creative Commons Attribution License, which permits unrestricted use, distribution, and reproduction in any medium, provided the original work is properly cited (http://creativecommons.org/licenses/by/4.0/deed.en).

Received: 20.01.2017

Accepted: 30.01.2017; Published: 04.04.2017 